\title{
West Indian Powderpost Drywood Termite, Cryptotermes brevis (Walker) (Insecta: Isoptera: Kalotermitidae) ${ }^{1}$
}

Rudolf H. Scheffrahn and Nan-Yao Su²

\section{Introduction}

Although described from specimens collected in Jamaica in 1853 and now occurring on all inhabited islands of the West Indies, Cryptotermes brevis is not indigenous to that region. Because this species only infests structural lumber, its origin remains unknown, but is likely indigenous to an obscure location in the Neotropics. Cryptotermes brevis was probably spread by wooden ships carrying wooden goods from port to port as development of the New World proceeded in the 17th century. This species is thought to have been introduced into the continental United States at Key West, Florida, before 1919. Some structure-infesting members of the genus Cryptotermes, like C. brevis, are called powderpost termites because their fecal pellets tend to be somewhat smaller than those of other drywood termite species. A second species of Cryptotermes, C. cavifrons Banks, is endemic to and very common in woodlands of peninsular Florida, however, C. cavifrons has a higher moisture requirement and is, as such, seldom a pest of buildings.

\section{Distribution}

Cryptotermes brevis is the most widespread drywood termite in the tropics worldwide, and in the United States is common throughout Hawaii, Florida, and some coastal regions of the Southeast. In Florida, populations of $C$. brevis tend to increase southward along the peninsula and concentrate in older buildings near the coast, but infestations can occur anywhere. Key West, Ft. Lauderdale, Miami, St. Petersburg, and Tampa have heavy populations of $C$. brevis. Some cities along the gulf coast, notably, New Orleans, Galveston, and Corpus Christi, are also afflicted with heavy resident populations.

\section{Description and Identification}

As with all termites, drywood termites are social insects, but unlike subterranean termites, they live entirely within the wood members they infest and obtain water adsorbed onto wood fibers and by metabolic processes. Drywood termites are generally larger and more cylindrical in body form compared to subterranean termites. Because their gallery systems are limited to and usually extend only a few meters within their home wood, drywood termites have

1. This document is EENY-079, one of a series of Featured Creatures from the Entomology and Nematology Department, Florida Cooperative Extension Service, Institute of Food and Agricultural Sciences, University of Florida. Published: April 1999. This document is also available on Featured Creatures Website at http://creatures.ifas.ufl.edu. Please visit the EDIS Website at http://edis.ifas.ufl.edu.

2. Rudolf H. Scheffrahn and Nan-Yao Su, professors, Department of Entomology and Nematology, Ft. Lauderdale Research and Education Center, Cooperative Extension Service, Institute of Food and Agricultural Sciences, University of Florida, Ft. Lauderdale, FL 33314.

The Institute of Food and Agricultural Sciences (IFAS) is an Equal Employment Opportunity - Affirmative Action Employer authorized to provide research, educational information and other services only to individuals and institutions that function without regard to race, creed, color, religion, age, disability, sex, sexual orientation, marital status, national origin, political opinions or affiliations. For information on obtaining other extension publications, contact your county Cooperative Extension Service office. Florida Cooperative Extension Service / Institute of Food and Agricultural Sciences / University of Florida / Larry R. Arrington, Interim Dean 




Figure 1. United States distribution of the West Indian powderpost drywood termite, Cryptotermes brevis (Walker). Credits: Rudolf H. Scheffrahn, University of Florida

proportionally shorter legs and move more slowly than their more far-ranging subterranean counterparts. Characters shared with other termites include chewing mouthparts for feeding on wood, well-developed tarsal claws for gripping wood surfaces, moniliform (bead-like) antennae, and blindness except in the reproductive caste.

Drywood termite colonies are composed of three primary castes: the reproductives (king, queen, and unmated winged forms called alates), soldiers, and immature reproductives or pseudergates (i.e.,"false workers"). The pseudergates excavate wood to feed themselves and the other caste members in the colony. Eggs and larvae (first few instars) are usually near galleries inhabited by the king and queen. All termite species are difficult to distinguish by immature or worker stages or by the wingless king or queen, therefore, soldiers or alates are best be used for species identification. Soldiers are present in colonies year round, while alates are formed about a month before swarming season.

Drywood termite alates have two pair of hairless, membranous wings that are about equal in size and shape and have three or four darkened and enlarged veins (subcosta and branches of the radial sector) in the leading (costal) margin of each wing. Termite alates are weak fliers and flights are slow and drifting, and wings are often shed within minutes of landing. The bodies of $C$. brevis alates are medium brown and are about 0.4 inches $(11 \mathrm{~mm})$ in length with wings. Shed wings are about $9 \mathrm{~mm}$ long and the median vein usually curves in the outer third to terminate in the

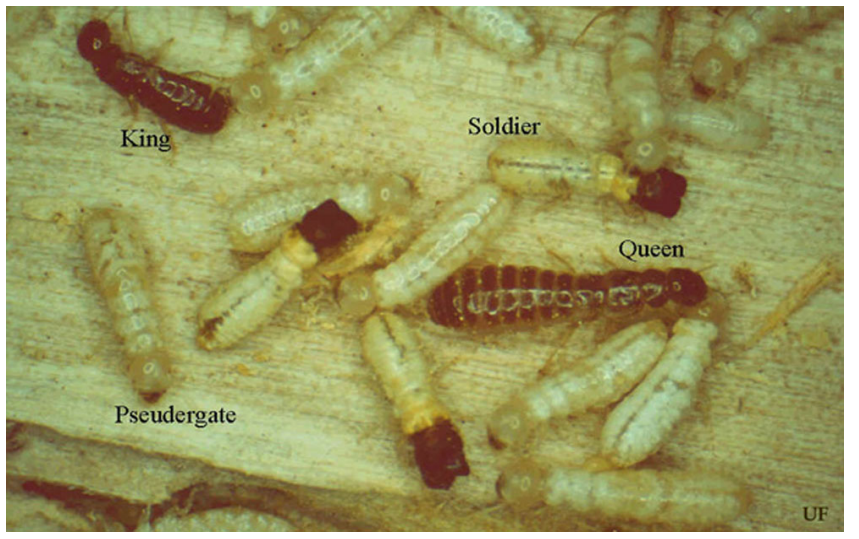

Figure 2. Castes (reproductive, soldiers, and pseudergates - immature reproductives) of the West Indian powderpost drywood termite, Cryptotermes brevis (Walker). Credits: Rudolf H. Scheffrahn, University of Florida

costal margin. Cryptotermes brevis wings have a prismatic sheen when dry.

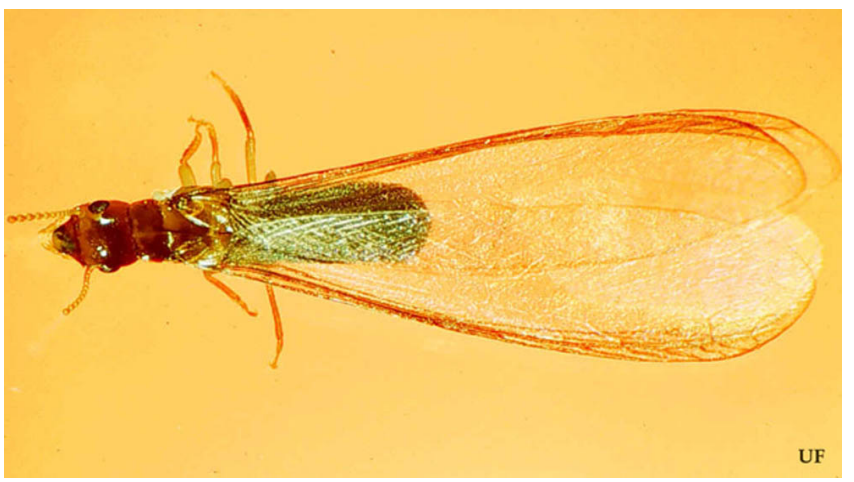

Figure 3. Alate (reproductive) of the West Indian powderpost drywood termite, Cryptotermes brevis (Walker). Credits: Rudolf H. Scheffrahn, University of Florida

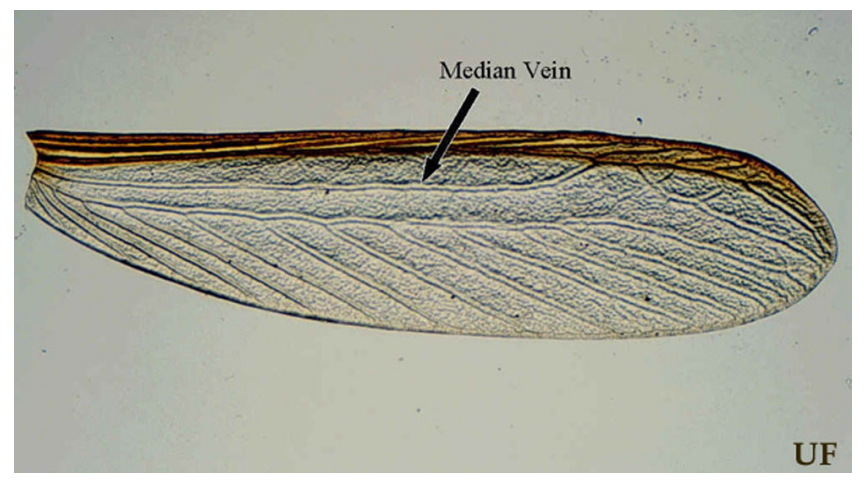

Figure 4. Wing of the West Indian powderpost drywood termite, Cryptotermes brevis (Walker). Credits: Rudolf $\mathrm{H}$. Scheffrahn, University of Florida

Cryptotermes brevis soldiers are about 4 to $5 \mathrm{~mm}$ long and have have a plug-like (phragmotic) head that is nearly black, deeply wrinkled, and is about 1.2 
to $1.4 \mathrm{~mm}$ wide. Their mandibles do not project nearly as far as those of the other drywood termite genera, but use their heads to plug-off galleries from invading ants. The pronotum of drywood termite soldiers is always as wide or wider than the head capsule.

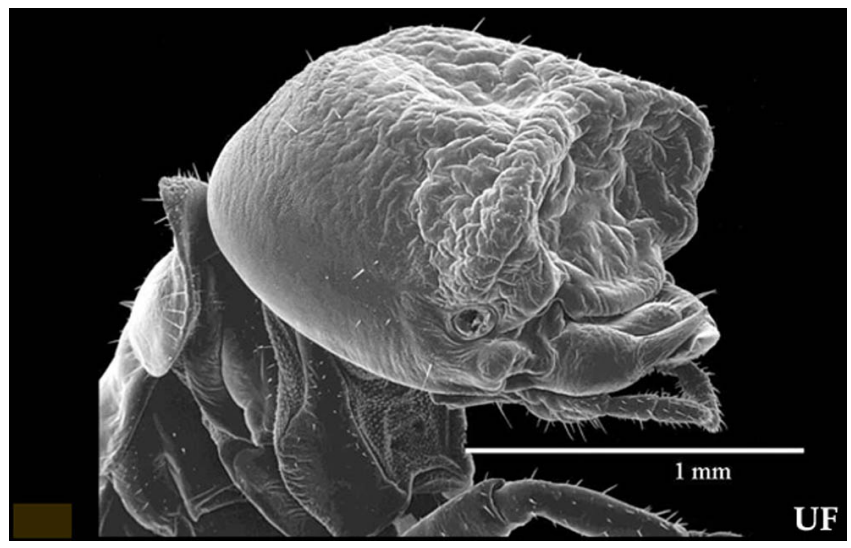

Figure 5. Soldier (antennae removed) of the West Indian powderpost drywood termite, Cryptotermes brevis (Walker). Credits: Rudolf H. Scheffrahn, University of Florida

\section{Life History}

Each year, a proportion of pseudergates in mature colonies molts into alates that leave the colony during a series of dispersal flights over a period of several weeks. This is the only time when colony members leave the confines of their excavated wood galleries and is often the first sign of an infestation. Alates of $C$. brevis fly between dusk and dawn from April through June and are attracted to lights. Occasional small flights in the fall have also been recorded. After a brief flight, the alates quickly shed their wings and segregate into male/female pairs. The male follows the female in tandem as they inspect wood surfaces for defects such as cracks, crevices, knots, or nail holes, which are preferred as foci for nuptial chamber excavation. Once the chamber is large enough to accommodate the pair, its opening is sealed with an intestinal secretion. During the first six months, the initial batch of eggs hatches into larvae. In the second or third year, the first soldier may appear along with additional brood. A colony matures in no less than five years, at which time it produces its first crop of alates. Colonies can live over 10 years and contain over a thousand members. Numerous colonies may live in close proximity and are thought to share gallery systems.
Twenty colonies (as counted by numbers of pairs of primary reproductives) have been recorded from a single wooden door.



Figure 6. Life cycle of the West Indian powderpost drywood termite, Cryptotermes brevis (Walker). Credits: Rudolf H. Scheffrahn, University of Florida

\section{Damage}

Colonies of all drywood termite species infest sound, solid hardwoods and softwoods, including all common building lumbers used in structural framing. Numerous colonies may inhabit a single structure. Cryptotermes brevis is more apt than the other species to infest smaller articles of furniture such as headboards, cabinets, and picture frames.

Pseudergates excavate galleries in sapwood in preference to heartwood, but show no preference between annual spring and summer growth rings. Because drywood termites seek protection from external predation, galleries are concealed beneath the wood surface. Sounding with a hard implement can locate hollowed-out wood. A very thin wood surface in late stages of attack may have a blistered appearance. External signs of infestations, however, most often consist of fecal pellets extruded from 0.04-0.08 inch (1-2 mm) diameter "kick-out" holes. Pellets will accumulate in piles directly beneath holes. Pile diameter is proportional to the height from which pellets fall. Drywood termite fecal pellets, with six longitudinal surfaces capped with one rounded and one more tapered end, are uniquely shaped compared to all other wood-infesting insects. Pellets vary in color from cream to red to black and are expelled periodically from different kick-out holes communicating with the gallery system. Pellets do not change in shape or color over time and their color is 
often unrelated to the wood from which they were expelled. Swarming alates, wings, and ejected fecal pellets are a sanitary nuisance, and pellets may present a slipping hazard on smooth floors.

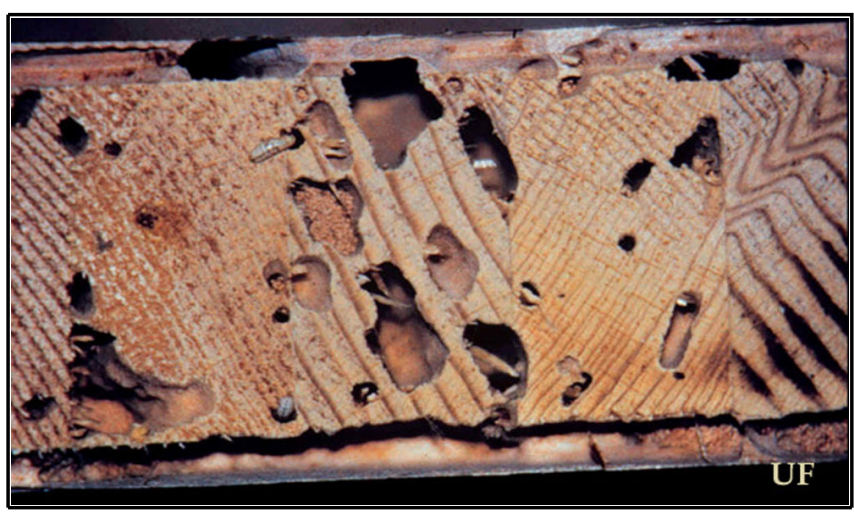

Figure 7. Damage (wooden door) caused by the West Indian powderpost drywood termite, Cryptotermes brevis (Walker). Credits: Rudolf H. Scheffrahn, University of Florida

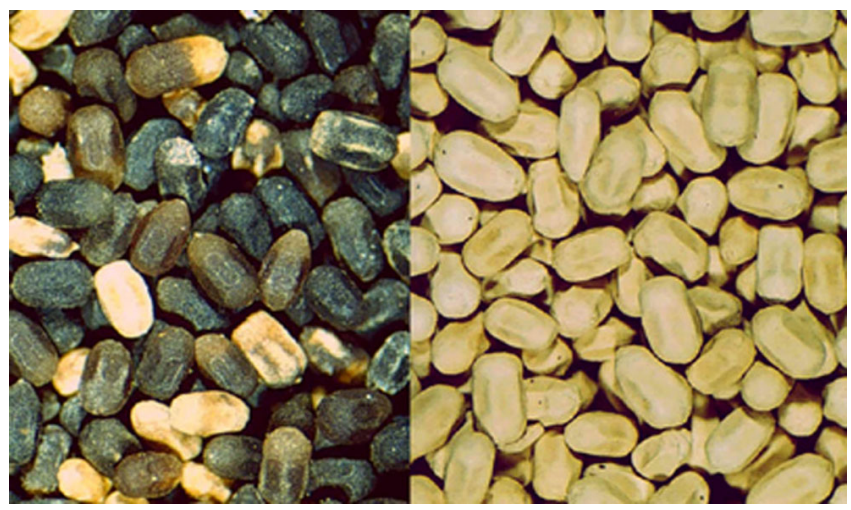

Figure 8. Pellets of the West Indian powderpost drywood termite, Cryptotermes brevis (Walker). Credits: Rudolf $\mathrm{H}$. Scheffrahn, University of Florida

\section{Pest Status}

Drywood termites are an almost ubiquitous part of older wooden structures in regions where they commonly occur. Structures only five to10 years old may harbor infestations requiring treatment.

Drywood termite control costs in the United States are estimated to exceed $\$ 300$ million annually with greatest losses occurring in southern California, peninsular Florida, and Hawaii. Cryptotermes brevis accounts for about \$120 million in the US and untold amounts worldwide.

\section{Management}

Preventative methods are aimed at excluding alates from structures, controlling reproductives, or preventing their nuptial chamber construction. Exclusion consists of "tight" building practices, caulking, and small mesh attic screening, but complete blockage of alate entry points is difficult. Attics and wall voids can be treated with desiccating or toxic dusts that kill freshly flown reproductives as they contact treated surfaces while searching for nest sites. Borate dusts have been shown to thwart nuptial chamber construction. Application of preventative chemicals is best done during the framing phase of construction when all wood is accessible to treatment. Reproductives will not infest lumber that has been pressure-treated with chromated copper arsenate (CCA) wood preservatives.

A broad array of remedial methods is available for treating drywood termite infestations. Whole-structure treatments include fumigation and heating to control all accessible and inaccessible colonies. Fumigation ("tenting") is a highly technical procedure which involves surrounding the structure with a gas-tight tarpaulin, releasing an insecticidal gas (usually sulfuryl fluoride) inside the enclosure, and aerating the fumigant after a set exposure time. Because of technical challenges, heat treatments usually are not applied to the entire building, but are limited to known areas of infestation, and along with excessive cold, are classified as compartmental treatments. Heat treatments are used to eradicate drywood termites from a portion of a house such as an attic, porch, or bedroom, or from an individual apartment or condominium unit inside a multi-family dwelling. Hot air is delivered using high-output propane heaters. Excessive cold is primarily used for treating wall voids or similar small enclosures in a structure. Liquid nitrogen is delivered into these voids until the temperature falls to a level lethal to drywood termites.

Local or "spot" treatments for drywood termite control include wood injection and surface applications, microwave energy, electrocution, and wood replacement. Wood injection or "drill-and-treat" applications use an insecticide that is injected into small holes drilled to intersect termite 
galleries. This is the simplest and most direct method of treatment. Spray and foam applications of products containing boron salts are applied to raw, uncoated wood surfaces. Because penetration depths of borate solutions and depth of drywood termite galleries vary, drill injection into infested wood should also be performed. Microwave energy, applied to relatively small sections of infested wood, kills termites by heating them. The electrocution method uses a hand-held "gun" which is passed slowly over the infested wood. The high voltage and low current energy emitted by the probe electrocutes termites in the immediate application area. Wood replacement allows for absolute removal of a drywood termite infestation if it is isolated to a wood member that can be detached relatively easily, as for example, a fascia board or a door.

Because drywood termites are hidden inside the wood they infest, it may be difficult to immediately verify the success of a given treatment. A swarm within a few years of treatment suggests either that the treatment was unsuccessful, infested wood was brought in, or a hidden, untreated, infestation was present and must now be treated. Accumulation of pellets, especially in a cone-shaped pattern, is also a sign of active drywood termites. All pellets should be removed after a treatment to insure that colony activity has ceased. A retreatment is warranted if new pellets are observed. Pellets may continue to trickle from wood after successful control if the wood member is periodically subjected to vibrations or jarring such as a door or door frame.

\section{Selected References}

Ebeling, W. 1978. Urban Entomology. University of California Press, Berkeley, Calif. 695 pp.

Edwards, R., A.E. Mill. 1986. Termites in Buildings. Their Biology and Control. Rentokil Ltd., East Grinstead, U.K. 261 pp.

Lewis, V.R., M.I. Haverty. 1996. Evaluation of six techniques for control of the western drywood termite (Isoptera: Kalotermitidae) in structures. J. Econ. Entomol. 89: 922-934.
Scheffrahn, R.H., J. R. Mangold, N.-Y. Su. 1988. A survey of structure-infesting termites of peninsular Florida. Florida Entomol. 71: 615-630.

Scheffrahn, R.H., N.-Y. Su, and P. Busey. 1997a. Laboratory and field evaluations of selected chemical treatments for control of drywood termites (Isoptera: Kalotermitidae). J. Econ. Entomol. 90: 492-502.

Scheffrahn, R.H., G.S. Wheeler, and N.-Y. Su. 1997b. Heat tolerance of structure-infesting drywood termites (Isoptera: Kalotermitidae) of Florida. Sociobiology 29: 237-245.

Scheffrahn, R.H., N.-Y. Su, J. Krecek, A. Van Liempt, B. Maharajh, and G. S. Wheeler. 1998. Prevention of Colony Foundation by the Drywood Termite, Cryptotermes brevis, and Remedial Control of Drywood Termites (Isoptera: Kalotermitidae) with Selected Chemical Treatments. J. Econ. Entomol. J. Econ. Entomol. 91: 1387-1396.

Su, N.-Y., and R.H. Scheffrahn. 1990.

Economically important termites in the United States and their control. Sociobiology 17: 77-94. 